\title{
ANALISIS IMPLEMENTASI STRATEGI PENGEMBANGAN BAITUL MAAL WA TAMWIL BEN SEJAHTERA KROYA DENGAN METODE SWOT DAN BALANCED SCORECARD
}

\section{Implementation Analysis of The Development Strategy of Baitul Maal Wa Tamwil Ben Sejahtera Kroya Using Swot Method and Balanced Scorecard}

\author{
Rifaul Muchlishoh ${ }^{1}$, Amin Syukron ${ }^{1}$, Christian Soolany, ${ }^{2, *}$ \\ ${ }^{1}$ Jurusan Teknik Industri - Fakultas Teknologi Industri - Universitas Nahdlatul Ulama Al Gazali Cilacap \\ Kesugihan, Cilacap, 53274, Indonesia \\ ${ }^{2}$ Jurusan Teknik Mesin - Fakultas Teknologi Industri - Universitas Nahdlatul Ulama Al Ghazali Cilacap \\ Kesugihan, Cilacap, 53274, Indonesia \\ *Korespondensi, Email: : christiansoolany@gmail.com
}

DOI: https://doi.org/10.20884/1.jaber.2021.2.1.4189

Naskah ini diterima pada 2 Mei 2021; revisi pada 5 Mei 2021; disetujui untuk dipublikasikan pada 18 Mei 2021

\begin{abstract}
ABSTRAK
Penelitian ini bertujuan untuk mengetahui strategi yang diterapkan oleh BMT Ben Sejahtera Kroya dalam pengembangan lembaganya guna mensejahterakan anggotanya dalam menghadapi perkembangan zaman. Penelitian ini menggunakan pendekatan deskriptif kualitatif. Data dikumpulkan dengan cara observasi, wawancara, kuesioner, dokumentasi. Analisis data dilakukan dengan cara mengukur visi dan misi menggunakan analisis SWOT. Analisa data dilakukan dengan cara mengukur masing-masing perspektif yakni finansial, customer, proses bisnis internal, serta pembelajaran dan pertumbuhan. Dari hasil penelitian menunjukkan bahwa berdasarkan analisis SWOT BMT Ben Sejahtera Kroya berada pada posisi kuadran I (Strenght dan Opportunity) yakni perusahaan menghadapi pasar yang besar dan juga memiliki nilai lebih dalam proses operasional. Dimana BMT Ben Sejahtera Kroya harus mampu memanfaatkan peluang yang ada dengan kekuatan dan kompetensi yang dimiliki. Berdasarkan hasil pengukuran kinerja dengan metode balanced scorecard BMT Ben Sejahtera Kroya dilihat dari empat perspektif secara garis besar sudah terpenuhi dengan sangat baik.
\end{abstract}

Kata kunci: Strategi Pengembangan, BMT Ben Sejahtera Kroya, Pengembangan Kelembagaan, Analisis SWOT, Balanced Scorecard.

\begin{abstract}
This study aims to determine the strategy implemented by BMT Ben Sejahtera Kroya in the development of its institution in order to prosper its members in the face of the times. This research use desciptive qualitative approach. Data were collected by means of observation, interviews, questionnaires, documentation. Data analysis is done by measuring the vision and mission using SWOT analysis. Data analysis is carried out by measuring each perspective, namely financial, customer, internal business processes, as well as learning and growth. The results showed that based on the SWOT analysis, BMT Ben Sejahtera Kroya was in the first quadrant position (Strength and Opportunity), namely the company faced a large market and also had more value in the operational process. Where BMT Ben Sejahtera Kroya must be able to take advantage of existing opportunities with their strengths and competencies. Based on the results of performance measurement using the Ben Sejahtera Kroya BMT balanced scorecard method, seen from four perspectives, the outline has been very well fulfilled.
\end{abstract}


Keywords: Development Strategy, BMT Ben Sejahtera Kroya, Institurional Development, SWOT Analysis, Balanced Scorecard

\section{PENDAHULUAN}

Saat ini, perkembangan bisnis perbankan syariah sangat pesat. Perkembangan ini juga didorong oleh peningkatan kinerja karyawan yang mampu berkompetensi dalam berbagai bidang untuk mencapai tujuan utama perusahaan. Oleh karena itu perusahaan dituntut untuk lebih meningkatkan kinerjanya dalam persaingan bisnis yang sangat ketat ini dengan perbaikan kinerjanya. Kunci persaingan dalam pasar global adalah kualitas total yang mencakup penekanan-penekanan pada kualitas produk, kualitas biaya atau harga, kualitas pelayanan, kualitas penyerahan tepat waktu, kualitas estetika dan bentuk-bentuk kualitas lain yang terus berkembang guna memberikan kepuasan terus menerus kepada pelanggan agar tercipta pelanggan yang loyal. Sehingga meningkatnya persaingan bisnis memacu manajemen untuk lebih memperhatikan sedikitnya dua hal penting yaitu "keunggulan" dan "nilai" (Chamdan, 2010). Pengukuran kinerja menggunakan metode balance scorecard sudah banyak di implementasikan di berbagai sektor usaha, penerapan metode balanced scorecard sebagai tolak pengukuran kinerja perusahaan (Ributari Nurgahayu \& Dwi Retnani, 2015), metode balanced scorecard terhadap peningkatan kinerja UMKM (Alimudin et al., 2019), penentuan Key Performance Indicator dengan metode balance scorecard pada perusahaan industry (Rokhim, 2017), analisis pencapaian strategi menggunakan balanced scorecard (Alimudin, 2017), implementasi strategi dan pengukuran kinerja lembaga keuangan (Perdana \& Retnani, 2019), perencanaan strategi pengembangan usaha kain tenun sutra dengan pendekatan metode balanced scorecard (Aulia \& Ikhwana, 2013), implementasi manajamen di pondok pesantren jamiyyah islamiyyah Tangerang Selatan (Saihu, 2019), dan penerapan manajemen strategi pada usaha gula merah (Rahmadi et al., 2018).

Berdasarkan kajian itu, makan akan diterapkan pada Lembaga pembiayaan islami di Baitul Maal Wa Tamwil. Baitul Maal Wa Tamwil (BMT) merupakan bagian dari bank syariah atau semacam Lembaga Swadaya Masyarakat (LSM) yang beroperasi seperti bank koperasi dengan pengecualian ukurannya yang kecil dan tidak mempunyai akses ke pasar uang. Baitul Maal Wa Tamwil (BMT) berfungsi menghimpun dan menyalurkan dana kepada masyarakat sebagaimana bank atau lembaga keuangan yang lain. BMT berdiri dengan gagasan fleksibilitas dalam menjangkau masyarakat kalangan bawah yaitu lembaga ekonomi rakyat kecil karena kebanyakan dari mereka adalah pedagang kecil yang tidak bisa memanfaatkan fasilitas kredit dari bank konvensional untuk mengembangkan usaha, hal ini disebabkan prosedur bank konvensional yang sulit serta kelemahan yang dimiliki oleh pedagang kecil dan pengusaha kecil dalam hal manajemen, pemasaran dan jaminan yang merupakan faktor-faktor penting bagi penilaian bank. BMT mengembangkan usaha- usaha produktif dan investasi dalam meningkatkan kualitas kegiatan pengusaha kecil bawah dan kecil dengan mendorong kegiatan menabung dan menunjang pembiayaan ekonomi dan BMT berfungsi sebagai suatu lembaga keuangan syariah (Hayati Ginting \& Ilyda, 2002).

Pemanfaatan media sosial sebagai media pemasaran dan informasi bagi nasabah belum mampu digunakan secara maksimal oleh karyawan. Hal ini diungkapkan oleh divisi SDI dan LITBANG pada wawancara terkait tentang permasalahan yang ada di BMT Ben Sejahtera Kroya. Dalam hal ini, metode yang sesuai adalah balanced scorecard (BSC). Karena balanced scorecard memiliki keistimewaan dalam hal cakupan pengukurannya yang cukup komprehensif karena selain tetap mempertimbangkan kinerja keuangan. Balaced scorecard juga mempertimbangkan kinerja-kinerja non keuangan, yaitu pelanggan, proses internal bisnis, serta pembelajaran dan pertumbuhan. Berdasarkan permasalahan diatas, maka penulis merasa tertarik untuk melakukan suatu penelitian dengan judul "Analisis Implementasi Strategi Pengembangan Baitul Maal Wa Tamwil (BMT) Ben Sejahtera Kroya dengan Metode SWOT dan Balanced Scorecard". Berdasarkan uraian diatas, maka tujuan dari penelitian ini adalah mengidentifikasi faktor-faktor lingkungan internal dan eksternal pengembangan BMT di kroya menggunakan 
metode SWOT serta memilih strategi bisnis yang tepat untuk diterapkan dalam pengembangan BMT di kroya melalui metode balanced scorecard. yaitu:

Berdasarkan uraian latar belakang diatas, maka perumusan masalah untuk penelitian ini

a. Bagaimana strategi pengembangan BMT Ben Sejahtera Kroya apabila diukur menggunakan Analsisis SWOT?

b. Bagaimana perancangan strategi dalam pengembangan BMT Ben Sejahtera Kroya dengan menggunakan metoda Balanced Scorecard untuk meningkatkan kinerja karyawan?

Adapun tujuan dari penelitian ini yaitu :

a. Mengetahui strategi prioritas dari penyilangan faktor-faktor internal dan eksternal pada matriks SWOT.

Mengetahui perancangan sistem pengukuran kinerja pada BMT Ben Sejahtera Kroya dengan metode Balanced Scorecard.

\section{METODE PENELITIAN}

\section{Alat dan Bahan}

Alat dan Bahan yang digunakan pada penelitian ini yaitu printer cannon MP 2800 dan kertas ukuran A4 untuk membuat kuesioner yang dibagikan kepada karyawan BMT Ben Sejahtera Kroya.

\section{Metode Penelitian}

Metode penelitian yang digunakan pada penelitian ini dibagi beberapa tahapan. Metode yang dilakukan peneliti diharapkan dapat memudahkan dalam penyusunan karya ilmiah yang disusun secara sistematis dengan teori pendukung. Penelitian ini menggunakan pendekatan kualitatif. Menurut (Sugiyono, 2018) metode kualitatif adalah metode penelitian yang berlandaskan pada filsafat postpositivisme, digunakan untuk meneliti pada kondisi objek yang alamiah, dimana peneliti adalah sebagai instrument kunci, teknik pengumpulan data dilakukan secara triangulasi (gabungan observasi, wawancara dan dokumentasi).

Penelitian ini dimulai dengan mengidentifikasi kegiatan proses bisnis internal lalu mengidentifikasi visi dan misi organisasi BMT Ben Sejahtera Kroya, data yang diperoleh dari hasil wawancara kepada pihak internal yang akan dijadikan Key Performance Indicator perusahaan. Pengumpulan data kualitatif yang digunakan seperti wawancara, observasi deskriptif serta dokumentasi, bertujuan untuk memberikan gambaran secara mendetail tentang latar belakang.

\section{Jenis dan Sumber Data}

Ada dua sumber data dalam penelitian ini antara lain sebagai berikut:

1. Data primer, sebagai sumber data utama dalam penelitian ini yang diambil dari hasil observasi dan wawancara atau menggunakan kuesioner kepada karyawan BMT Ben Sejahtera Kroya.

2. Data sekunder, merupakan data yang didapat dari studi literatur untuk mempelajari teori dari ilmu pengetahuan yang berkaitan dengan topik penelitian. Data ini berguna sebagai landasan teori yang dapat diperoleh dari studi pustaka. 


\section{Prosedur Pengumpulan Data}

Dalam prosedur pengumpulan data teknik yang digunakan adalah sebagai berikut:

1. Studi Pendahuluan

Pada tahap ini peneliti melakukan kunjungan ke BMT Ben Sejahtera Kroya dengan tujuan memcari dan mengumpulkan data-data yang dibutuhkan dalam penelitian seperti profil perusahaan termasuk visi dan misi BMT. Melakukan permohonan izin secara formal untuk melakukan penelitian studi lapangan.

2. Studi Pustaka

Tahap selanjutnya adalah studi pustaka dimana studi ini dilakukan untuk mencari teori-teori, temuan dan peneliti lain yang berkaitan dengan penelitian. Pada penelitian ini peneliti mengumpulkan informasi tentang teori strategi pengembangan, analisis SWOT, Balanced Scorecard, Key Performance Indicator.

3. Studi Lapangan

Pada tahap ketiga yaitu studi lapangan yang dilakukan dengan terjun langsung kelapangan untuk memperoleh keterangan. Adapun prosedur pengumpulan data studi lapangan yang digunakan.

1) Observasi

Observasi yang dilakukan oleh peneliti disini yaitu observasi deskriptif menurut (Sugiyono, 2018) Observasi Deskriptif pada tahap ini peneliti belum membawa masalah yang akan diteliti, maka peneliti melakukan penjelajahan umum, dan menyeluruh, melakukan deskripsi terhadap semua yang dilihat, didengar, dan dirasakan. Observasi tahap ini sering disebut Grand Tour Observation, dan peneliti menghasilkan kesimpulan pertama.

2) Wawancara

Wawancara adalah bentuk komunikasi langsung antara peneliti dan responden. Komunikasi berlangsung dalam bentuk tanya jawab dalam hubungan tatap muka, sehingga gerak dan mimik responden merupakan pola media yang melengkapi kata-kata verbal. Dalam hal ini, peneliti melakukan wawancara dengan perwakilan yang terlibat dalam penelitian. Wawancara digunakan untuk mengetahui permasalahan yang dihadapi BMT Ben Sejahtera Kroya.

3) Dokumenter

Dokumen adalah catatan tertulis tentang berbagai kegiatan atau peristiwa pada waktu yang lalu. Dalam hal ini, penulis mengambil beberapa data antara visi, misi, program kerja BMT Ben Sejahtera

\section{Waktu dan Tempat Pelaksanaan}

Untuk waktu dan tempat pelaksanaan penelitian ini yaitu di BMT Ben Sejahtera Kroya, yang beralamat di Jl. Sindoro Kroya No.1, Banjar, Kroya Cilacap dengan waktu penelitian dari Bulan Agustus s/d Oktober 2019

\section{HASIL DAN PEMBAHASAN}

Pembahasan analisis SWOT dalam penelitian ini yaitu menggunakan metode Internal Factor Evaluation dan Eksternal Factor Evaluation. Dalam internal factor evaluation terdapat kekuatan dan kelemahan internal perusahaan dan pada eksternal factor evaluation perusahaan terdapat peluang dan ancaman eksternal perusahaan. Berikut ini adalah hasil internal factor evaluation dan eksternal factor evaluation BMT Ben Sejahtera Kroya 


\section{Internal Factor Evaluation}

Faktor internal BMT Ben Sejahtera Kroya ditunjukkan pada Tabel 1. Dari hasil pembobotan Internal Factor Evaluation yaitu dengan hasil rata-rata tertimbang kekuatan internal 4,05 dan kelemahan internal 1,7, dari hasil tersebut kemudian dihitung untuk mendapatkan hasil internal factor evaluation adalah sebesar $+2,35$. Hal ini dapat disimpulkan bahwa dalam proses bisnis internalnya, BMT Ben Sejahtera Kroya lebih didominasi oleh faktorfaktor yang menjadi kekuatan internal. Jika dilihat dari jumlah nilai rata-rata tertimbangnya, diketahui nilai totalnya sebesar 5,76 yang melebihi angka (dari skala 1,0 - 4,0).

Hal tersebut menunjukkan bahwa pihak manajemen BMT Ben Sejahtera Kroya selalu memperhatikan faktor-faktor kekuatan maupun kelemahan yang dimiliki, dan mampu merespon dengan baik faktor-faktor internal perusahaan untuk dapat tetap bersaing dengan perusahaan lainnya.

Tabel 1. Internal factor evaluation

\begin{tabular}{|c|c|c|}
\hline \multicolumn{3}{|c|}{ Faktor Internal Evaluasi } \\
\hline No & Kekuatan Internal & Kelemahan Internal \\
\hline 1. & Memiliki surat ijin legalitas & Minimnya modal usaha untuk pengembangan \\
\hline & Gedung milik sendiri & $\begin{array}{l}\text { Minimnya media promosi produk-produk BMT Ben } \\
\text { Sejahtera kepada masyarakat (secara online) }\end{array}$ \\
\hline 3. & Letak kantor yang strategis & $\begin{array}{l}\text { Sistem antian pelayanan pembiayaan yang } \\
\text { manual }\end{array}$ \\
\hline & $\begin{array}{l}\text { Pembinaan rutin terhadap } \\
\text { SDMnya }\end{array}$ & $\begin{array}{l}\text { Belum adanya lembaga } \mathrm{R} \& \mathrm{D} \text { pengembangan } \\
\text { perusahaan }\end{array}$ \\
\hline 5. & Keamanannya terjamin & \\
\hline & $\begin{array}{l}\text { Job description yang jelas dan } \\
\text { terfokus }\end{array}$ & \\
\hline & $\begin{array}{l}\text { Solidaritas yang terbagun sangat } \\
\text { kuat diantara pengurus dan } \\
\text { pengelola }\end{array}$ & \\
\hline & $\begin{array}{l}\text { Mempunyai } 6 \text { kantor cabang } \\
\text { lintas daerah }\end{array}$ & \\
\hline & $\begin{array}{l}\text { Pertumbuhan asset dari tahun ke } \\
\text { tahun selalu naik }\end{array}$ & \\
\hline & $\begin{array}{l}\text { Kurva keuangan selalu naik } \\
\text { setiap tahunnya }\end{array}$ & \\
\hline & Penerapan strategi jemput bola & \\
\hline
\end{tabular}

\section{Eksternal Factor Evaluation}

Faktor eksternal BMT Ben Sejahtera Kroya ditunjukkan pada Tabel 2. Dari hasil pembobotan Eksternal Factor Evaluation yaitu dengan hasil rata-rata tertimbang peluang eksternal 3,51 dan ancaman eksternalnya 2,51. Dari hasil tersebut kemudian dihitung untuk mendapatkan hasil Eeksternal Factor Evaluation 1,00. Dan jumlah rata-rata tertimbang Eksternal Factor Evaluation 6,02.

Jika melihat hasil rata-rata tertimbang bahwa pihak manajemen BMT Ben Sejahtera Kroya menjadikan faktor-faktor ancaman dari para pesaing lembaga keuangan lainnya untuk mengantisipasi dan bertindak waspada terhadap nasabah yang beralih kepada lembaga keuangan lainnya. 
Tabel 2.

Eksternal factor evaluation

\begin{tabular}{|c|c|c|c|c|}
\hline \multirow{2}{*}{ No } & Faktor Eksternal & \multirow{2}{*}{$\begin{array}{l}\text { (0-1) } \\
\text { Bobot }\end{array}$} & \multirow{2}{*}{$\begin{array}{c}(1-4) \\
\text { Peringkat }\end{array}$} & \multirow{2}{*}{$\begin{array}{l}\text { Rata-Rata } \\
\text { Tertimbang }\end{array}$} \\
\hline & Peluang Eksternal & & & \\
\hline 1. & $\begin{array}{l}\text { Memperluas jaringan mitra ke lintas } \\
\text { propinsi }\end{array}$ & 0,12 & 3 & 0,36 \\
\hline 2. & $\begin{array}{l}\text { Masyarakat sekitar BMT mayoritas } \\
\text { muslim }\end{array}$ & 0,25 & 4 & 1,00 \\
\hline 3. & Promosi melalui internet & 0,11 & 2 & 0,22 \\
\hline 4. & $\begin{array}{l}\text { Dekat dengan sentral ekonomi, pasar } \\
\text { dan sentral industri pemerintahan }\end{array}$ & 0,21 & 4 & 0,84 \\
\hline 5. & $\begin{array}{l}\text { Perkembangan ekonomi syariah } \\
\text { sudah cukup pesat di } \\
\text { seluruh dunia khususnya di Indonesia }\end{array}$ & 0,11 & 3 & 0,33 \\
\hline 6. & $\begin{array}{l}\text { Adanya Perhatian dari pemerintah } \\
\text { daerah kepada BMT }\end{array}$ & 0,12 & 2 & 0,24 \\
\hline \multirow[t]{2}{*}{7.} & Fatwa MUI tentang haramnya riba & 0,13 & 4 & 0,52 \\
\hline & Total & 1 & & 3,51 \\
\hline 1. & $\begin{array}{l}\text { Ancaman Eksternal } \\
\text { Persaingan harga dengan } \\
\text { kompetitor }\end{array}$ & 0,12 & 2 & 0,24 \\
\hline 2. & $\begin{array}{l}\text { Resign nya anggota dari } \\
\text { departemen collector }\end{array}$ & 0,09 & 1 & 0,09 \\
\hline 3. & $\begin{array}{l}\text { Kurangnya pemahaman } \\
\text { masyarakat terkait dengan } \\
\text { perbankan syariah } \\
\text { Masih adanya anggota yang }\end{array}$ & 0,25 & 3 & 0,75 \\
\hline 4. & $\begin{array}{l}\text { kurang disiplin dalam melunasi } \\
\text { pembiayaan }\end{array}$ & 0,20 & 3 & 0,60 \\
\hline 5. & $\begin{array}{l}\text { Masih adanya msyarakat yang } \\
\text { kurang memahami konsep syariah }\end{array}$ & 0,19 & 3 & 0,57 \\
\hline 6. & $\begin{array}{l}\text { Pesaing yang sudah mengaplikasikan } \\
\text { teknologi yang lebih canggih untuk } \\
\text { menjamin kenyamanan dan kemudahan } \\
\text { nasabahnya dalam } \\
\text { bertransaksi }\end{array}$ & 0,13 & 2 & 0,26 \\
\hline & Total & 1 & & 2,51 \\
\hline
\end{tabular}

\section{Analisis Internal Factor Evaluation dan Eksternal Factor Evaluation}

Dari hasil pembobotan yang telah diolah kemudian dimasukan kedalam diagram kartesius untuk mengetahui posisi kuadrant BMT Ben sejahtera Kroya. Hasil dari diagram kartesius menunjukkan bahwasannya koordinat BMT Ben Sejahtera Kroya berada di titik $(2,35 ; 1,00)$ atau 
dapat diartikan Strength $(2,35)$ dan Opportunity $(1,00)$ lebih tepatnya posisi koordinat dari perusahaan berada pada Kuadran I (Strategi Agresif).

Hasil evaluasi yang dilakukan menunjukkan strategi yang harus dilakukan perusahaan yaitu dengan memanfaatkan seluruh kekuatan untuk merebut dan memanfaatkan peluang besarbesaran. Strategi yang harus diterapkan dalam kondisi ini adalah mendukung kebijakan pertumbuhan yang agresif, seperti memperluas target pemasaran dengan promosi besar-besaran.

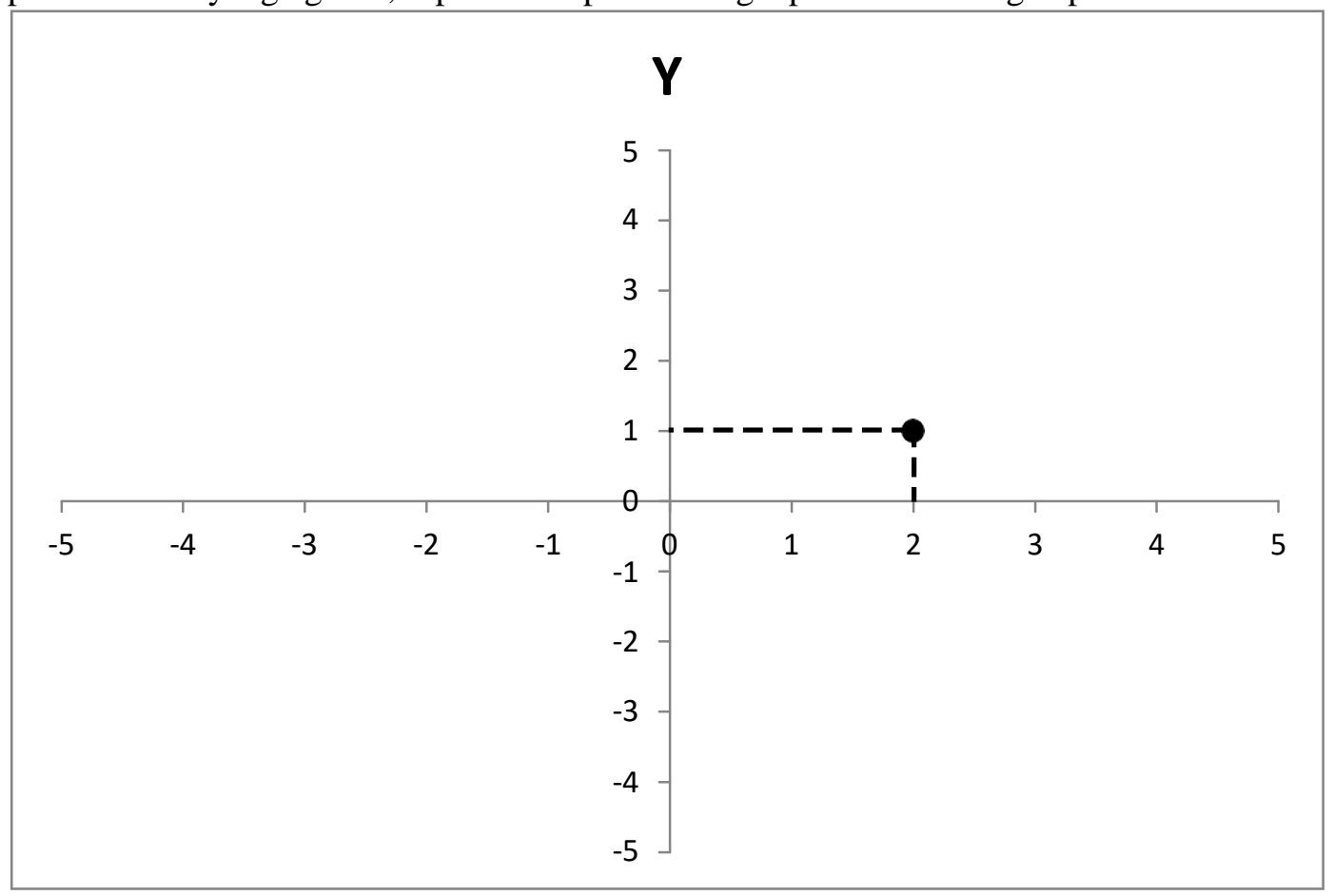

Gambar 1. Diagram kartesius

\section{Balanced Scorecard}

Implementasi balanced scorecard yang digunakan sebagai pengusulan strategi perusahaan untuk menyeimbangkan kinerja organisasi perusahaan yang tidak hanya dari segi finansialnya saja namun dari segi non finansialnya BMT Ben Sejahtera Kroya.

Dari 4 perspektif balanced scorecard terdapat beberapa ukuran kinerja yang dapat digunakan sebagai strategi dalam meningkatkan kinerja organisasi perusahaan.

1. Perspektif Finansial

1) Meningkatkan SHU (selisih hasil usaha)

2) Meningkatkan pendapatan

3) Meningkatkan pembiayaan

2. Perspektif Customer

1) Bertambahnya anggota yang loyal dengan BMT

2) Standarisasi pelayanan kantor dan lapangan

3. Perspektif Internal Process Business

1) Membuat aturan SOP dan SOM sesuai dengan jobdesk

2) Standar kinerja keberhasilan individu dan lembaga

4. Perspektif Learning and Growth

1) Terbentuk karyawan yang berkarakter sesuai value BMT

2) Terimplementasi budaya kerja disetiap karyawan 


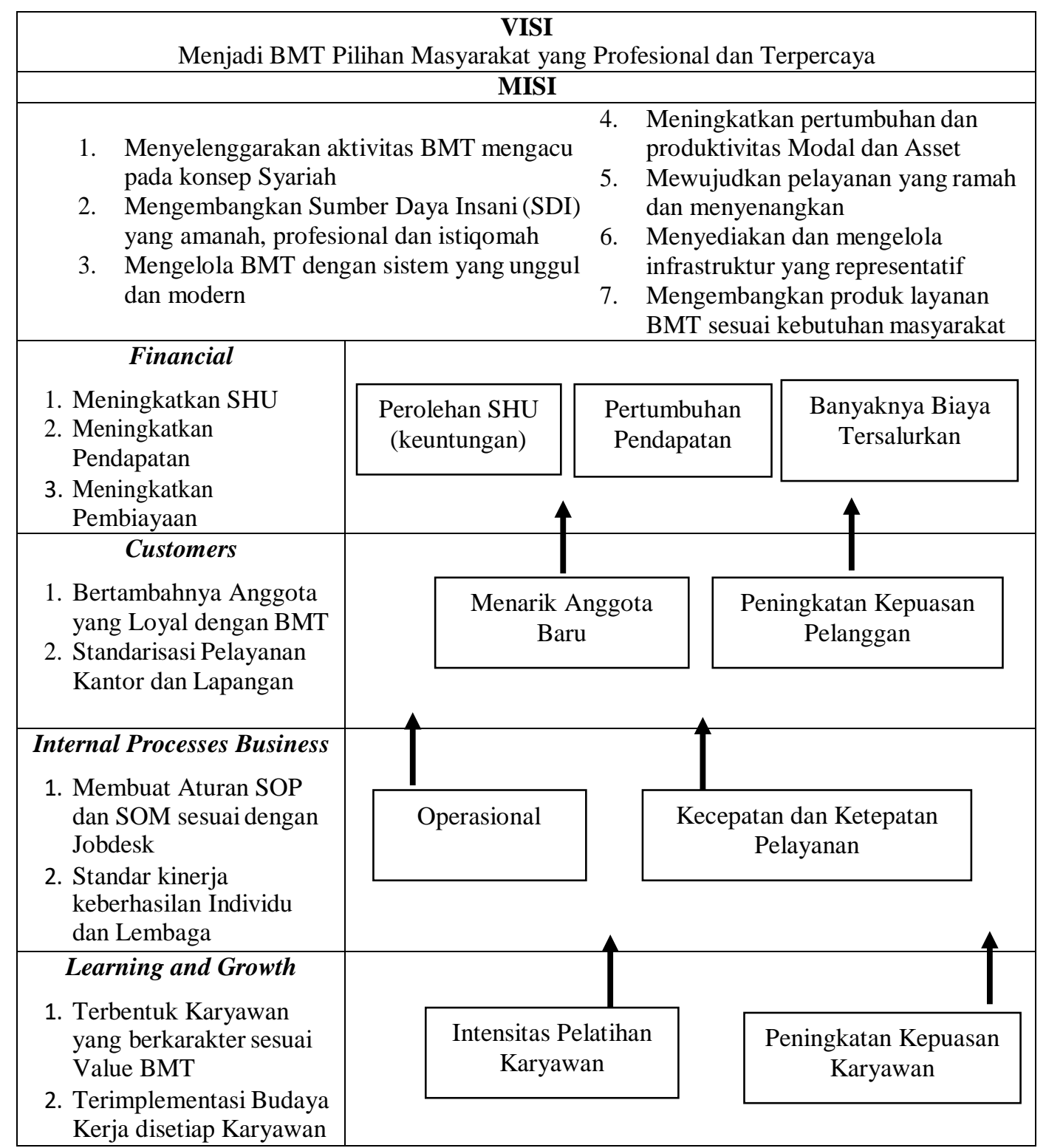

Gambar 2. Strategi Map Balanced Scorecard BMT Ben Sejahtera Kroya

Penarikan prioritas strategi balanced scorecard yang dilakukan yaitu dengan menggunakan metode brainstorming kepada pihak SDI dan LITBANG BMT Ben Sejahtera Kroya terdapat prioritas utama dalam meningkatkan kinerja organisasi perusahaan dengan menggunakan balanced scorecard sebagai berikut :

Tabel 3. Prioritas strategi balanced scorecard BMT Ben Sejahtera Kroya

\begin{tabular}{ccc}
\hline No & Perspektif & Key Performance Indicator \\
\hline 1. & Finansial & Meningkatkan SHU \\
2. & Customer & Standarisasi Pelayanan \\
3. & Proses Bisnis Internal & Kecepatan dan Ketepatan Karyawan \\
4. & Pembelajaran dan Pertumbuhan & Intensitas Pelatihan Karyawan \\
\hline
\end{tabular}


Dari hasil brainstroming dengan menggunakan metode $5 \mathrm{~W}+1 \mathrm{H}$ dapat disimpulkan bahwa prioritas dari misi BMT Ben Sejahtera Kroya dalam menghadapi kondisi persaingan bisnis sebagai berikut:

1. Menyelenggarakan aktivitas BMT yang mengacu pada konsep syariah dengan cara penerapan konsep dalam anggota untuk meningkatkan pemahaman pada anggota.

2. Memprospek atau mengajak orang baik yang belum gabung di BMT maupun yang sudah untuk menanam modal di BMT dengan cara mengadakan pertemuan rutin antar anggota untuk meningkatkan pertumbuhan dan produktivitas modal dan asset.

3. Melakukan intensitas pelatihan terhadap karyawan, dengan cara mengadakan pelatihan rutin setiap minggu, bulan bahkan tahunan untuk mengembangkan Sumber Daya Insani yang amanah, profesional dan istiqomah.

Mewujudkan pelayanan yang ramah dan menyenangkan dengan cara menerapkan sistem jemput bola, dengan memudahkan nasabah dalam betransaksi sehingga dapat meningkatkan pendapatan perusahaan.

\section{KESIMPULAN}

Berdasarkan analisis SWOT BMT Ben Sejahtera Kroya berada pada posisi kuadran I (Strenght dan Opportunity) yakni perusahaan menghadapi pasar yang besar dan juga memiliki nilai lebih dalam proses operasional. Dimana BMT Ben Sejahtera Kroya harus mampu memanfaatkan peluang yang ada dengan kekuatan dan kompetensi yang dimiliki. Bahwa ketika perusahaan berada pada titik quadrant I harus melakukan hal sebagai berikut: Menggunakan seluruh kekuatan untuk merebut dan memanfaatkan peluang sebesar-besarnya. Berdasarkan hasil analisis usulan strategi dengan metode balanced scorecard pada BMT Ben Sejahtera Kroya terdapat 9 strategi yang terbagi dalam 4 perspektif. Untuk hasil prioritas dalam mecapai visi dan misi organisasi perusahaan BMT Ben Sejahtera Kroya memiliki key performance indicator dari setiap perspektif.

\section{DAFTAR PUSTAKA}

Alimudin, A. (2017). Analisis Pencapaian Strategi Menggunakan Balanced Scorecard. Jurnal Pendidikan Ekonomi Dan Bisnis (JPEB), 5(2), 194-205. https://doi.org/10.21009/jpeb.005.2.6

Alimudin, A., Falani, A. Z., Mudjanarko, S. W., \& Limantara, A. D. (2019). Analisis Pengaruh Penerapan Perspektif Balanced Scorecard Terhadap Peningkatan Kinerja UMKM. Ekonika: Jurnal Ekonomi Universitas Kadiri, 4(1), 1. https://doi.org/10.30737/ekonika.v4i1.337

Aulia, D., \& Ikhwana, A. (2013). Perencanaan Strategi Pengembangan Usaha Kain Tenun Sutra Dengan Pendekatan Metode Balanced Scorecard (Studi Kasus Di Pabrik Sutra Tiga Putra). Jurnal Kalibrasi, 10(1), 1-12. https://doi.org/10.33364/kalibrasi/v.10-1.1

Chamdan, N. U. (2010). Penerapan Metode Balanced Scorecard Sebagai Pengukuran Kinerja Pada Lembaga Keuangan Syariah (BMT) Bina Insan Mandiri Gondangrejo. Skripsi, 17.

Hayati Ginting, I. I., \& I. S. (2002). Analisis Strategi Pengembangan BMT (Baitul Maal Wa Tamwil) Di Kota Medan. Jurnal Ekonomi dan Keuangan, 2(11), 672-673.

Perdana, R. A., \& Retnani, E. D. (2019). Implementasi Strategi Dan Pengukuran Kinerja. Jurnal Ilmu Dan Riset Akuntansi, 8(4), 1-18.

Rahmadi, R., Soolany, C., \& Pratama, A. R. (2018). PENERAPAN MANAJEMEN STRATEGI PEMASARAN UNTUK MENINGKATKAN DAYA JUAL PRODUK UMKM GULA MERAH DI KABUPATEN CILACAP Reza. Jti, 2(2), 1-6.

Ributari Nurgahayu, E., \& Dwi Retnani, E. (2015). Penerapan Metode Balanced Scorecard 
Sebagai Tolok Ukur Pengukuran Kinerja Perusahaan. Jurnal Ilmu \& Riset Akuntansi, 4(10), 1-16.

Rokhim, M. (2017). Studi Kasus Tentang Performance Management di Sebuah Perusahaan Manufaktur Ban: Key Performance Indicator (KPI) untuk Industrial Engineering dengan Metode Balanced Score Card. Jurnal Teknik Industri, 18(2), 168. https://doi.org/10.22219/jtiumm.vol18.no2.168-175

Saihu, S. (2019). Implementasi Manajemen Balanced Scorecard Di Pondok Pesantren Jam'Iyyah Islamiyyah Tangerang Selatan. Mumtaz: Jurnal Studi Al-Qur'an Dan Keislaman, 3(1), 1-22. https://doi.org/10.36671/mumtaz.v3i1.30

Sugiyono. (2018). Metode Penelitian Evaluasi (Pendekatan Kuantitatif, Kombinasi). Bandung: Alfabeta 